\section{at AMS headquarters}

On the 8th of November Executive Director Spengler went to Scott Air Force Base, Ill., for the MAC Reserve Policy Council meeting. While at Scott AFB he visited Headquarters Air Weather Service.

The Executive Director flew to Washington on the 12th of the month to join AMS President Alfred K. Blackadar in representing the Society at the reception and dinner held at the National Museum of Natural History to mark the Centenary of Conservation of United States Fisheries Resources. The affair was sponsored by the Natural Resources Council of America in cooperation with the Smithsonian Institution. While in Washington, Mr. Spengler and Prof. Blackadar conferred with Dr. Robert M. White, Chairman of the AMS Planning Commission.

Mr. Spengler went to Philadelphia on the 17th to preside as President of the Board Meeting of the Council of Engineering and Scientific Society Executives, held at the American Society for Testing and Materials. He was accompanied by Evelyn Mazur and Matthew Toyli who surveyed hotel facilities in Philadelphia for the AMS conference on the urban environment to be held in that city next fall. They later visited Drexel Institute of Technology's Department of Physics and met with local AMS chapter officers concerning program plans for the forthcoming conference.

On the 18th the Executive Director attended the 1st Steering Committee Meeting of the Air Force Weather Mission -1985, held at MITRE Corporation.

The AMS Film Panel met at 45 Beacon St. on 22-23 No- vember. Those attending were: Prof. Louis J. Battan, University of Arizona, Tucson; Dean Charles L. Hosler, Pennsylvania State University, University Park, Pa.; Dr. Helmut E. Landsberg, University of Maryland, College Park; Prof. Verne N. Rockcastle, Cornell University, Ithaca, N. Y.; and John Davidson, Davidson Films, San Francisco, Calif.

On the 23rd the Executive Director flew to Washington to attend the meeting of the Steering Committee for the Joint Conference on Technology and Governance in Achieving Environmental Quality, September 20-22, 1972, Washington, D. C., sponsored by several scientific and engineering societies. Mr. Spengler was elected chairman of the Steering Committee.

Mr. Spengler, Evelyn Mazur and Matthew Toyli flew to Fort Lauderdale, Fla., for the AMS Conference on the Interaction of the Sea and Atmosphere on the 30th.

During November, the following people visited AMS headquarters: Joe Bale, New York; Eric A. Walther, Flagstaff, Ariz.; John J. Foley, Randolph, Mass.; Robert J. Lavaller, Bedford, Mass.; John H. Kentry, Chelmsford, Mass.; Mrs. Lee C. Moorehead, Sr., Decatur, Ill.; Mrs. Lee C. Moorehead, Jr., Carbondale, Ill.; S. G. Geotz, Saugus, Mass.; Mrs. Henry E. Hellmann, West Newton, Mass.; Graham W. Dunlop, Sharon, Mass.; Ralph E. Huschke, Rolling Hills, Calif.; L. F. Westmoreland, San Pedro, Calif.; C. N. Touart, Lexington, Mass.; Paul M. Fye, Woods Hole, Mass.; David Scott, Woods Hole, Mass.; Navin Ellworth, Boston, Mass.; Robert H. Cole, Providence, R. I.; Fred Wanglerdorf, Woods Hole, Mass.; Edwin D. Brooler, Concord, Mass.; H. Brooks, Cambridge, Mass.; A. Hoover, Osterville, Mass.; Michael J. Smith, Somerville, Mass.; Gerald Wambolt, Lincoln, Mass.; Bruce A. Egan, Newton, Mass.; Alfred J. McNiff, Jr., Boston, Mass.; Robert B. Sykes, Oswega, N. Y.; Charlette O. Oldfer, Boston, Mass.; B. H. Woodman, Haverhill, Mass.; Arnold A. Barnes, Jr., Weston, Mass.; David Salstein, Boston, Mass.; Edmund Potry, Brookline, Mass.; Mr. and Mrs. Donald F. Moore, Rockville, Md.; James B. Butterfield, Penibroke, Bermuda; and Thomas Slattery, Gladstone, N. H.

\title{
election resullts
}

The names of the newly chosen President-Elect and Councilors of the American Meteorological Society were announced on 12 January 1972 at the 52nd annual business meeting of the Society at the Fairmont-Roosevelt Hotel, New Orleans, La.

The President-Elect, who will assume the post of President in 1973, is Dr. William W. Kellogg, Associate Director, National Center for Atmospheric Research, Boulder, Colo.

Five councilors are elected to three-year terms of office each year-four by the Society's members and one by the Council. Elected to the Council by the members of the Society were Prof. David Atlas, Department of Geophysical Sciences, The University of Chicago; Dr. Robert D. Fletcher, Chief Scientist, Air Weather Service, Scott Air Force Base, Illinois; Dr. Patrick D. McTaggart-Cowan, Executive Director, Science Council of Canada, Ottawa, Ontario; Dr.
Frederick G. Shuman, Director, National Meteorological Center, National Weather Service, National Oceanic and Atmospheric Administration, Washington, D. C. Mr. Max A. Kohler, Chief Hydrologist, Office of Hydrology, National Weather Service, National Oceanic and Atmospheric Administration, was elected by the Council. The term of office of the five new councilors is three years, starting 12 January 1972.

An amendment to the By-Laws was approved which provides that, if the President decides that action by the Council is urgent, he may direct a vote to be taken by telephone or telegram. In this case, telegraphic confirmation must be received from each voting Councilor by the SecretaryTreasurer within a time limit set by the President.

Prof. Richard J. Reed, Department of Atmospheric Sciences, University of Washington, Seattle, last year's President-Elect, assumed office as President for 1972. 